\title{
Potential applications of MEG3 in cancer diagnosis and prognosis
}

\author{
Yuqing He ${ }^{1,3, *}$, Yanhong Luo ${ }^{2, *}$, Biyu Liang ${ }^{2, *}$, Lei $\mathrm{Ye}^{2}$, Guangxing $\mathrm{Lu}^{2}$ and Weiming $\mathrm{He}^{2}$ \\ ${ }^{1}$ Institute of Medical Systems Biology, Guangdong Medical University, Dongguan 523808, China \\ ${ }^{2}$ Department of Epidemiology and Medical Statistics, Guangdong Medical University, Dongguan 523808, China \\ ${ }^{3}$ Key Laboratory for Medical Molecular Diagnostics of Guangdong Province, Guangdong Medical University, Dongguan 523808, China \\ *Authors contributed equally to this work
}

Correspondence to: Yuqing He, email: dr.hyq@hotmail.com

Keywords: cancer, long noncoding RNAs, maternally expressed gene 3, apoptosis, MEG3

Received: June 01, 2017

Accepted: July 25, 2017

Published: August 04, 2017

Copyright: He et al. This is an open-access article distributed under the terms of the Creative Commons Attribution License 3.0 (CC BY 3.0), which permits unrestricted use, distribution, and reproduction in any medium, provided the original author and source are credited.

\section{ABSTRACT}

LncRNAs are emerging as integral functional and regulatory components of normal biological activities and are now considered as critically involved in the development of different diseases including cancer. In this review, we summarized recent findings on maternally expressed gene 3 (MEG3), a noncoding IncRNA, locates in the imprinted DLK1-MEG3 locus on human chromosome 14q32.3 region. MEG3 is expressed in normal tissues but is either lost or decreased in many human tumors and tumor derived cell lines. Studies have demonstrated that MEG3 is associated with cancer initiation, progression, metastasis and chemo-resistance. MEG3 may affect the activities of TP53, MDM2, GDF15, RB1 and some other key cell cycle regulators. In addition, the level of MEG3 showed good correlation with cancer clinicopathological grade. In summary, MEGs is an RNA-based tumor suppressor and is involved in the etiology, progression, and chemosensitivity of cancers. The alteration of MEG3 levels in various cancers suggested the possibility of using MEG3 level for cancer diagnosis and prognosis.

\section{INTRODUCTION}

Cancer is one of the main causes of death worldwide. A number of independent studies have demonstrated the involvement of noncoding RNAs, such as small nucleolar RNAs (snoRNAs), microRNAs (miRNAs), as well as long noncoding RNAs (lncRNAs) in cancer development [1-3]. LncRNAs are located in both intergenic and intronic regions of protein coding genes, and are frequently regulated and transcribed independently from the surrounding protein coding genes $[4,5]$. Studies have shown that lncRNAs play an important role in transcriptional regulations by modulating promoter accessibility through chromatin reorganization by affecting processes like histone modification [6]. LncRNAs also affect the activity of miRNA, the subcellular localization of proteins and the production of endogenous siRNA [7-10].

Recent studies suggest some lncRNAs such as GAS5, p21, H19, HOTAIR and PTENP1 may play a role in tumor suppression by affecting cell proliferation, invasion and metastasis [11-16]. In addition, the expression of some lncRNAs is also associated with the effectiveness of cancer chemotherapy [2, 17, 18]. Therefore, some lncRNAs may be used as potential therapeutic targets for cancer treatment and biomarkers for the diagnosis and prognosis of cancers [19-23]. Maternally expressed gene 3 (MEG3) is an lncRNA which expresses in many normal tissues. However, it is frequently either lost, mutated or decreased level in many human tumors and tumor derived cell lines [22, 24, 25]. Restoring proper MEG3 expression level inhibits tumor cell proliferation and induces tumor cell apoptosis as well as autophagy [26, 27]. These findings suggest MEG3 is one of the lncRNAs with tumor suppressor activity [28].

In this review, we summarized recent studies on MEG3 associated aberrant expression and its effects in cancers, and explored the potential of using MEG3 as biomarker for cancer diagnosis and prognosis.

The correlation of MEG3 expression with cancers

MEG3 is located in the chromosome 14 DLK1MEG3 imprinting region, containing multiple imprinted 
genes [25, 29, 30]. Besides MEG3, this region has a number of snoRNAs and miRNAs (Figure 1). Transcripts in this region are tightly regulated through methylation at the imprinting control regions [24, 25, 31]. The DLK1-MEG3 region has two key differentially methylated regions (DMRs) on the paternal allele, one called intergenic DMR (IG-DMR) located about $13 \mathrm{~kb}$ upstream of the MEG3 transcription start site and the other, MEG3-DMR, overlapped with the MEG3 promoter region [32, 33]. The IG-DMR is the major imprinting control element and MEG3-DMR is responsible for the maintaining of proper allelic expression of transcripts in this region. The mature MEG3 RNA consists of ten exons with a length of about 1,600 nt [25]. Abundant levels of MEG3 have been shown in various tissues including brain, adrenal gland, placenta, testes, ovary, pancreas, spleen, mammary gland, and liver [25].

Recent studies demonstrated decreased MEG3 levels in a variety of primary human cancers (Supplementary Table 1) $[16,18,24,25,31-73]$ and cancer derived cell lines (Table 1) [16, 18, 24, 31, 32, 34-36, 38, 41, $44,46-54,56,57,59,60,62-64,74-77]$. For example, MEG3 expression level is decreased in lung cancer [38], hepatocellular cancer [34], prostate cancer [37], multiple myeloma [33], meningioma [65], gastric cancer [35], and glioma [36]. In addition, loss of MEG3 expression was observed in the majority of nonfunctioning pituitary adenomas (NFPAs) [40, 45], neuroblastoma [31] and renal cell carcinoma [46]. Similar changes in MEG3 levels have also been found in various brain, bladder, bone marrow, breast, cervix, colon, liver, lung, meninges, and prostate cancers-derived cell lines (Table 1). Studies also reported that deletion of the MEG3 locus usually led to more aggressive cancers and MEG3 expression level correlated with tumor grade and prognosis in meningiomas [25], colorectal cancer (CRC) [54], NFPA [45], gastric cancer (GC) and cervical cancer [23, 49, 50]. For examples, Yin et al. analyzed $62 \mathrm{CRC}$ cases and demonstrated that a lower MEG3 level correlates with lower pathological grade, deeper tumor invasion, and advanced TNM (tumor node metastasis) stage [54]. Li et al. found MEG3 expression level is significantly lower in invasive NFPAs compared to noninvasive NFPAs [45]. Sun et al. reported that downregulated MEG3 is associated with poor prognosis and promotes cell proliferation in gastric cancer [50]. These findings suggest the level of MEG3 not only contributed to cancer development but also associated with pathological grade of the cancer and prognosis of the cancer patients. Recent meta-analysis studies also demonstrate the association of MEG3 level with cancer stages and survival outcome $[22,78]$.

\section{MEG3 inhibits cell proliferation and induces apoptosis in cancer}

Restoring the expression of MEG3 impedes cancer cell proliferation in vitro. For example, MEG3 inhibits proliferation and induces apoptosis in cancer cell lines including MG63, OS-732, SaOS, G292, and 143B (osteosarcoma) [79], OVCAR3 and A2780 [26], MDAMB-231, MCF-10A and MCF7 (breast) [27], HeLa (cervix), C-33A (cervix) [49], A549/DPP (lung) [38], $\mathrm{PRC} / \mathrm{PRF} / 5$ (liver) [41], U251 (brain) U87MG (brain) [36], HCT116 (colon) and DLD1 (colon) [54] (Table 1). There is also ample evidence showing MEG3 may affect the growth and differentiation of cells in vivo (Table 2). For example, studies have shown that restoring the expression of $M E G 3$ suppresses tumor growth in nude mice (Table 2) [34, 38, 44, 46, 54, 60, 62, 80-82].

Several Meg3 knockout (KO) mouse models have been used to study the function of MEG3 in vivo. The KO mouse model created by Zhou et al. carries a deletion of a $5 \mathrm{~kb}$ genomic region containing the first five exons and a small portion of the Meg3 promoter [81]. Mice carrying the paternal allele deletion are alive and normal. However, mice with deletion at the maternal allele died perinatally with major skeletal muscle defects, and the expression of both Meg3 and the downstream Meg8 was not detectable. Takahashi et al. created another Meg3 KO mouse with a $10 \mathrm{~kb}$ deletion of the genome containing the MEG3DMR and the first five exons of the Meg3 gene [83]; the mice with deletion on the maternal allele died 4 weeks after birth. Surprisingly, mice with homozygous deletion survived and grew to fertile adults [83]. In Takahashi's KO mice, it did not affect the methylation status of the IGDMR [83], but in Zhou's KO mice the IG-DMR region is hypermethylated [81]. This suggests MEG3-DMR may affect the methylation status of IG-DMR and once Meg3-DMR is deleted the IG-DMR will be methylated. Therefore, one of the possible functions of Meg3-DMR is to maintain an active (unmethylated) status in the IG-DMR region which allows the expression of downstream MEGs. A Meg3 KO generated by Gordon et al. showed an increase of brain microvessel formation in the Meg3 null embryos. This finding suggests MEG3 may affect the activities of genes involved in VEGF angiogenic pathway [81, 84].

\section{Epigenetic regulation of transcripts in the MEG3 region}

\section{MEG3 and DNA methylation}

Different mechanisms may contribute to the decrease or loss of MEG3 expression in cancers, including hypermethylation of the regulatory regions and deletions of the gene, as well as post translational degradation via miRNAs. Among them the hypermethylation in the MEG3 promoter and IG-DMR regions probably play the most important role for the decrease of MEG3 expression in cancers $[32,33]$. The MEG3 promoter region is GC-rich and overlaps with the MEG3-DMR. The expression of MEG3 can be modulated by changing the methylation state of its promoter and MEG3-DMR regions [85, 86]. 
For example, in human NFAPs the methylation levels in both the IG-DMR and MEG3 promoter regions are higher than in normal pituitary $[32,40]$. Astuti et al. also showed that the MEG3-DMR is completely methylated in neuroblastoma cell lines and hypermethylated MEG3 promoter is associated with down regulation of MEG3 and upregulation of DLK1 expression [31]. In neuroblastoma and pheochromocytoma tissues, the aberrant methylation of the MEG3 promoter correlated with decreased MEG3 level in $25 \%$ and $10 \%$ of the cases, respectively [31]. The silenced MEG3 expression in ovarian cancer is also due to promoter region hypermethylation which may also contribute to the progression of cancer development [33, 48]. Increased methylation in IG-DMR was also found in ovarian cancer and NSCLC (non-small cell lung cancer) derived cell lines $[44,48]$.

The degree of IG-DMR methylation showed a positive correlation with tumor grade and overall survival (OS) [25]. For example, the percentages of methylated CpG in IG-DMR are 50.1, 56.4, 61.0 and $68.8 \%$ in normal meninges, grade I, grade II, and grade III meningiomas respectively [25]. The level of MEG3 promoter region (MEG3-DMR) methylation is associated with OS of acute myeloid leukemia (AML) patients with myelodysplastic syndrome (MDS). The MEG3-DMR hypermethylation can be detected in $50 \%$ of patients with AML with MDS compared to only $34.9 \%$ of the patients with just MDS [85]. These studies suggest aberrant methylation of the MEG3 locus may be accentuated during cancer progression and the degree of MEG3 suppression is associated with the overall aggressiveness of cancers.

\section{SnoRNAs}

SnoRNAs are involved in post-transcriptional modifications and maturation of ribosomal RNAs and transfer RNAs. It can be divided into two large families: C/D box containing snoRNAs and H/ACA box snoRNAs. The C/D box snoRNAs are mainly responsible for methylation (2'-O-methylation) and H/ACA snoRNAs

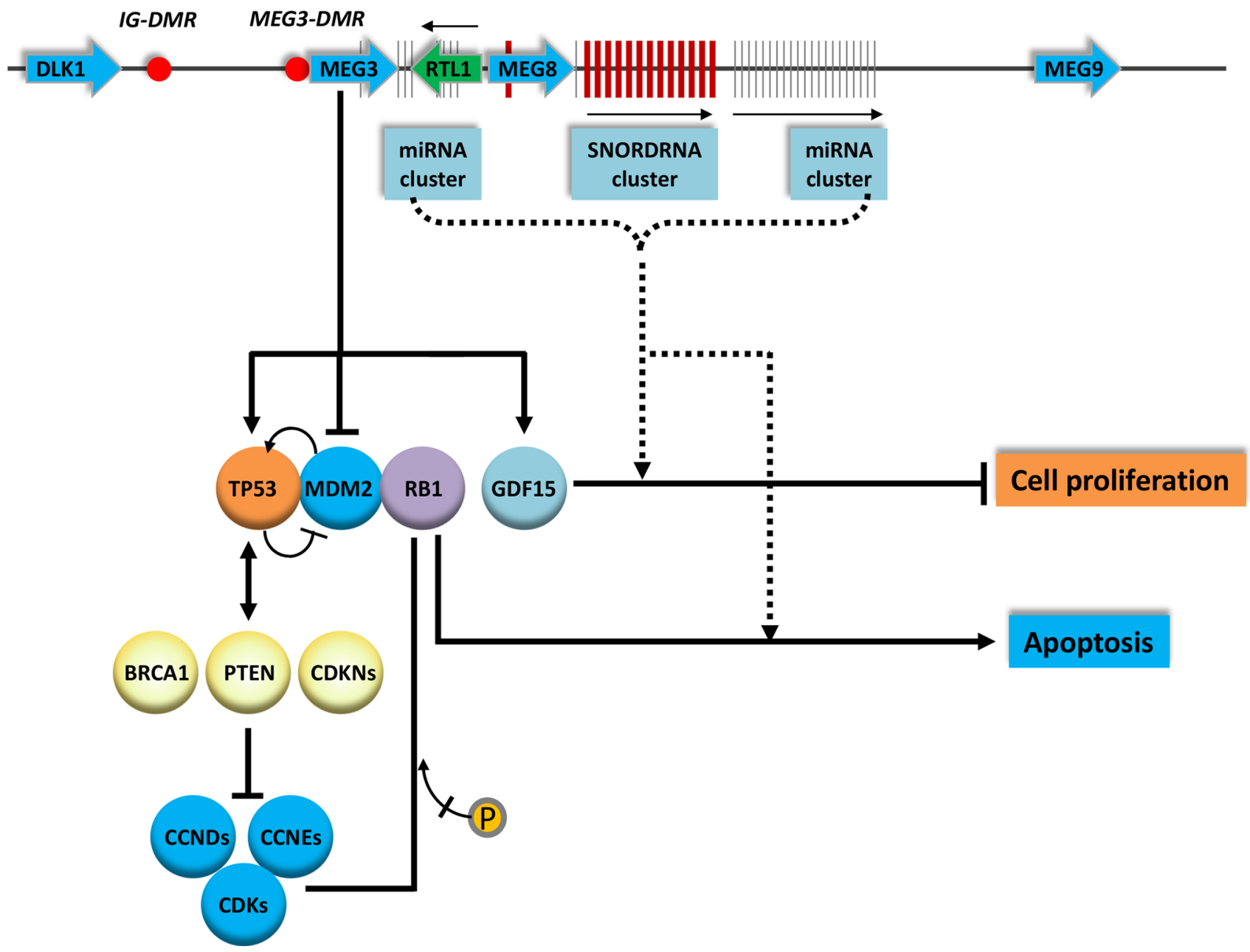

Figure 1: Genomic organization and schematic illustration on the involvement of MEG3 on cancer development. The genes, mRNA and snoRNAs are indicated and the transcription orientations are indicated by arrows. The red dots represent differentially methylated regions. The schematic interactions of MEGs with key genes involved in cell proliferation and apoptosis are indicated. The arrows indicate activation. The doted lines are putative interactions. 


\section{Table 1: Changes of MEG3 expression level in different cancer cell lines}

\begin{tabular}{|c|c|c|c|c|c|}
\hline Reference & Cancer type & Cell lines & MEG3 Level & Methods & Potential function and mechanism \\
\hline Li et al., 2017 [68] & AML & $\begin{array}{l}\text { THP-1, HL-60, CCL-240 and } \\
\text { CRL-1582 }\end{array}$ & Down & qRT-PCR & MEG3 down regulates miR-184 expression in Leukemia \\
\hline Lyu et al., 2017 [69] & AML & $\begin{array}{l}\text { K562, TF-1, MOLM-13, U937, } \\
\text { NB4, Kasumi-1, KG-1 and HL-60 }\end{array}$ & Down & qRT-PCR & $\begin{array}{l}\text { Dysregulation of MEG3 expression correlates with WT1 } \\
\text { or TET } 2 \text { mutations status, which probably plays an } \\
\text { important role in AML pathogenesis. }\end{array}$ \\
\hline Zhang et al., 2017 [71] & $\mathrm{BC}$ & $\begin{array}{l}\text { MDA-MB-231, MCF-10A and } \\
\text { MCF-7 }\end{array}$ & Down & qRT-PCR & $\begin{array}{l}\text { MEG3 expression associated with TNM stage and lymph } \\
\text { nodes metastasis. Lower MEG3 predicted a poor DFS and } \\
\text { OS for patients }\end{array}$ \\
\hline Zhang et al., 2017 [23] & $\mathrm{CC}$ & HeLa and CaSki & Down & qRT-PCR & $\begin{array}{l}\text { The low expression of MEG3 is likely due to promoter } \\
\text { hypermethylation. }\end{array}$ \\
\hline Hu et al., 2016 [74] & $\begin{array}{l}\text { Pancreatic } \\
\text { cancer }\end{array}$ & PANC-1 and SW1990 cells & Down & RT-PCR & $\begin{array}{l}\text { Fenofibrate inhibits pancreatic cancer cells proliferation } \\
\text { mediated by upregulation of MEG3 }\end{array}$ \\
\hline Li et al., 2016 [56] & Glioma & U251, U87 and A172 & Down & qRT-PCR & $\begin{array}{l}\text { DNMT1-mediated MEG3 hypermethylation causes the } \\
\text { loss of MEG3 expression, followed by the inhibition of } \\
\text { the p53 pathways }\end{array}$ \\
\hline Zhang et al., 2016 [63] & $\mathrm{CC}$ & HeLa and CaSki & Down & qRT-PCR & $\begin{array}{l}\text { MEG3 may interact with miR-21-5p to affects the post- } \\
\text { transcriptional network }\end{array}$ \\
\hline Zhou et al., 2015 [57] & $\mathrm{GC}$ & MKN45 and 7901 & Down & qRT-PCR & miR-141 could interact with MEG3 and target E2F3 \\
\hline Peng et al., 2015 [59] & $\mathrm{GC}$ & $\begin{array}{l}\text { HGC-27,MGC-803, MKN-45, } \\
\text { SGC-7901, BGC-823 and AGS }\end{array}$ & Down & qRT-PCR & $\begin{array}{l}\text { MEG3 could up-regulated Bcl-2 via its competing } \\
\text { endogenous RNA activity on miR-181a }\end{array}$ \\
\hline Luo et al., 2015 [60] & $\mathrm{PC}$ & PC3 and DU145 & Down & qRT-PCR & $\begin{array}{l}\text { MEG3 inhibited the expression of cell cycle regulatory } \\
\text { protein Cyclin D1 and induced cell cycle arrest in G0/G1 } \\
\text { phase }\end{array}$ \\
\hline Yin et al., 2015 [54] & $\mathrm{CRC}$ & HCT-116 and DLD-1 cell lines & Down & qRT-PCR & MEG3 inhibits cell proliferation through TP53 activation. \\
\hline Wang et al., 2015 [51] & $\mathrm{RCC}$ & RCC cell lines $786-0$ and SN1 & Down & qRT-PCR & $\begin{array}{l}\text { MEG3 induces apoptosis by inhibiting the BCL-2 } \\
\text { expression and activating the mitochondrial pathway. }\end{array}$ \\
\hline Gao et al., 2015[77] & $\mathrm{RB}$ & Retinoblastoma cell & Down & qRT-PCR & $\begin{array}{l}\text { Decreased expression of } \mathrm{MEG} 3 \text { contributes to } \\
\text { retinoblastoma progression and affects retinoblastoma } \\
\text { cell growth by regulating the activity of } \mathrm{Wnt} / \beta \text {-catenin } \\
\text { pathway. }\end{array}$ \\
\hline Zhuo et al., 2015 [34] & $\mathrm{HCC}$ & HCC cell lines & Down & qRT-PCR & UHRF1 regulates MEG3 level via DNMT1 and TP53 \\
\hline Xia et al., 2015 [18] & $\mathrm{LC}$ & Lung cancer cell lines A549/DDP & Down & qRT-PCR & $\begin{array}{l}\text { MEG3 regulates TP53, } \beta \text {-catenin and survivin expression. } \\
\text { Cisplatin treatment decreases the expression levels of } \\
\text { MEG3. }\end{array}$ \\
\hline Liu et al., 2015 [38] & LAD & A549/DDP cells & Down & Microarray & $\begin{array}{l}\text { MEG3 induces the activation of TP53 and Bcl-xl in LAD } \\
\text { cells. }\end{array}$ \\
\hline Zhuang et al., 2015 [52] & MM & MSCs cells & Down & qRT-PCR & $\begin{array}{l}\text { MEG3 played an essential role in osteogenic } \\
\text { differentiation of the bone marrow MSCs, partly by } \\
\text { activating BMP4 transcription. }\end{array}$ \\
\hline Wang et al., 2015 [16] & PTC & TPC-1 and HTH83 cells & Down & qRT-PCR & $\begin{array}{l}\text { RAC1 was negatively regulated by MEG3 at the post- } \\
\text { transcriptional level, through a specific target site within } \\
\text { the } 3 \text { 'UTR. }\end{array}$ \\
\hline Modali et al., 2015 [62] & PNT & Mouse insulinoma cell lines & Down & qRT-PCR & $\begin{array}{l}\text { DNA demethylating drugs reduce mouse insulinoma cell } \\
\text { proliferation and restore MEG3 expression. }\end{array}$ \\
\hline Parekh et al., 2015 [75] & MEN1 & Menin-deficient fat-cell & Down & Microarray & $\begin{array}{l}\text { Menin deficiency could result in fat cell hypertrophy and } \\
\text { differential gene expression from the methylated MEG3 } \\
\text { locus. }\end{array}$ \\
\hline Qi et al., 2015 [76] & $\mathrm{CRC}$ & Colorectal cancer cell & Down & qRT-PCR & $\begin{array}{l}\text { Decreased expression of MEG3 is associated with cell } \\
\text { invasion and metastasis. }\end{array}$ \\
\hline Yan et al., 2014 [35] & $\mathrm{GC}$ & SGC-7901 and BGC-823 & Down & qRT-PCR & $\begin{array}{l}\text { The suppression of miR-148a may contribute to the down- } \\
\text { regulation of MEG3 in gastric cancer by modulating the } \\
\text { activity of DNMT1. }\end{array}$ \\
\hline Sun et al., 2014 [50] & GC & GC cell lines & Down & qRT-PCR & $\begin{array}{l}\text { MEG3 may function as a tumor suppressor by activating } \\
\text { TP53 in gastric cancer. }\end{array}$ \\
\hline Sheng et al., 2014 [48] & EOC & Ovarian cancer cell lines & Down & qRT-PCR & $\begin{array}{l}\text { Decreased expression of MEG3 in EOC is due to promoter } \\
\text { hypermethylation. }\end{array}$ \\
\hline Greife et al., 2014 [24] & $\mathrm{UC}$ & Urothelial cancer cell lines & Down & qRT-PCR & $\begin{array}{l}\text { Down regulation of DLK1 and MEG } 3 \text { is caused by DNA } \\
\text { hypermethylation. }\end{array}$ \\
\hline Jia et al., 2014 [47] & TSCC & SCC-15 and CAL 27 & Down & qRT-PCR & $\begin{array}{l}\text { Antitumor effects of MEG3 are mediated by TP53 } \\
\text { activation in TSCC. }\end{array}$ \\
\hline Qin et al., 2013 [49] & $\mathrm{CC}$ & CC lines HeLa and C-33A & Down & qRT-PCR & MEG3 induces G2/M cell cycle arrest and apoptosis. \\
\hline
\end{tabular}




\begin{tabular}{|c|c|c|c|c|c|}
\hline Lu et al., 2013 [44] & NSCLC & NSCLC cell lines & Down & qRT-PCR & $\begin{array}{l}\text { Decreased MEG3 level in NSCLC tissues could be } \\
\text { affected by DNA methylation. MEG3 regulates cell } \\
\text { proliferation and apoptosis via activation of TP53. }\end{array}$ \\
\hline Ying et al., 2013 [53] & $\mathrm{BC}$ & Bladder cancer cells & Down & qRT-PCR & $\begin{array}{l}\text { Downregulated MEG3 activates autophagy and increases } \\
\text { cell proliferation in BC. }\end{array}$ \\
\hline Wang et al.,2012 [36] & Glioma & U251 and U87 MG cells & Down & qRT-PCR & $\begin{array}{l}\text { MEG3 expression is decreased in glioma cell lines and } \\
\text { effects TP53 and genes required for TP53 activation. }\end{array}$ \\
\hline Braconi et al., 2011 [41] & $\mathrm{HCC}$ & HCC cell lines (PLC/ PRF/5) & Down & qRT-PCR & $\begin{array}{l}\text { Deregulated miR-29a level in HCC affects MEG3 } \\
\text { expression through promoter hypermethylation. }\end{array}$ \\
\hline Kawakami et al., 2006 [46] & $\mathrm{RCC}$ & Human renal cells & Lost & RT-PCR & $\begin{array}{l}\text { Gain of methylation upstream of MEG3 leads to down } \\
\text { regulation of DLK1 in RCC. }\end{array}$ \\
\hline Astuti et al., 2005 [31] & NB & Neuroblastoma cell & Lost & RT-PCR & $\begin{array}{l}\text { The loss of MEG3 expression is associated with MEG3 } \\
\text { DMR hypermethylation. }\end{array}$ \\
\hline Zhao et al., 2005 [32] & PT & MCF7 and HeLa cells & Lost & qRT-PCR & $\begin{array}{l}\text { Hypermethylation of the promotor region is associated } \\
\text { with the loss of MEG } 3 \text { expression. }\end{array}$ \\
\hline Zhang et al., 2003 [64] & NFPA & HeLa, MCF-7, Neuroglioma H4 & Lost & RT-PCR & $\begin{array}{l}\text { MEG3 has a strong ability to inhibit proliferation of } \\
\text { several carcinoma cell lines and NFPA. }\end{array}$ \\
\hline
\end{tabular}

Abbreviations: CRC, Colorectal cancer; CC, cervical cancer; RCC, Renal Cell Carcinoma; RB, Retino-blastoma; HCC, Hepatocellular Carcinoma; LC, lung cancer; LAD; lung adenocarcinoma; MM, Multiple Myeloma; PTC, papillary thyroid carcinoma; MEN1, multiple endocrine neoplasia type 1; GC, gastric cancer; EOC, epithelial ovarian cancer; UC, urothelial carcinoma; TSCC, tongue squamous cell carcinoma; BC, bladder cancer; NSCLC, Non-small cell lung cancer; NB, neuroblastoma; PT, Pituitary Tumors; PNT, pancreatic neuroendocrine tumor; DNMT1, DNA (cytosine-5-)-methyltransferase 1; M-PCR, Methylation-Specific Polymerase Chain Reaction; DLK1, delta-like 1 homolog; UHRF1, ubiquitin-like with PHD and ring finger domains 1; MSCs, Mesenchymal stromal cells.

are for pseudouridylation of ribosomal RNAs [87, 88]. The MEG3 genomic region contains a cluster of C/D box snoRNAs - member of the SNORD112 (1 copy), SNORD113 (9 copies) and SNORD114 (31 copies) families [89, 90] (Figure 1). The SNORD112 and some of the SNORD113 members are located in the intron of MEG8 gene. Like what has been observed in MEG3, some snoRNA expression levels were also decreased in AML and ALL cells compared to normal cells [91]. Opposite to the effect of MEG3, over-expressing SNORD114 member induces K562 and HCT116 cell proliferation [92] and suppressing the snoRNA induces cell death. Further studies revealed that SNORD114 promotes cell cycle progression through $\mathrm{G} 0 / \mathrm{G} 1$ to $\mathrm{S}$ phase transition [91]. The level of SNORD114-3, one of the snoRNAs in the DLK1-MEG3 snoRNAs cluster showed good correlation with MEG3 expression, which suggests the SNORD114-3 and MEG3 probably are co-regulated by the IG-DMR and MEG3-DMR regions. These findings indicate some of the snoRNAs in the region may have similar involvement in cell proliferation and tumor progression as MEG3.

\section{microRNAs}

MiRNAs are involved in the regulation of all aspects of cellular function including cytokine signaling cascades, DNA methylation, oncogenic kinase expression, and others that are important for the development and progression of cancers [61, 93-95]. Besides snoRNAs, the MEG3 region contains a number of miRNAs and some of these are located in the intron of MEG3, MEG8 and RTL1 (retrotransposon-like 1) transcripts (Figure 1). Some miRNAs in the locus are probably derived from the MEG3 primary transcript and under MEG3 promoter control [9698]. Like MEG3, the levels of these miRNAs have also been shown to affect cancer development and influence cancer cell chemosensitivity, which is directly linked to the prognostic outcome of different cancers. For example, Shih et al. reported 29 miRNAs that were associated with disease outcome in advanced ovarian cancer patients and 11 of the 29 miRNAs are located in the DLK1-MEG3 cluster [99]. Nine of those 11 miRNAs including miR-433, miR-127, miR-381, miR-377, miR-299-3p, miR-409-3p, miR-154, miR-382, and miR-376c are associated with OS. In a separate study, the increase of miR-376c level in ovarian cancer cells was found to inhibit cisplatin induced cell death [100]. The miRNAs in this region have also been shown to be involved in the progression of esophageal squamous cell carcinoma (ESCC) and hepatocellular carcinoma (HCC) [101-105]. In addition, miR-495, miR134, miR-409-3p, miR-496, miR-379, miR-369-3p in the cluster are linked to the tumor invasion depth in gastric cancer $[104,106]$. Besides that miR-376c has been shown to be associated with nodal metastasis in gastric cancer and miR-494 is significantly correlated with gastric cancer stage. The study also indicated that miR-495, miR-433, and miR-410 levels can be used to predict both disease free survival (DFS) and OS in gastric cancer patients [104]. The methylation pattern in the MEG3 DMR as well as the expression profile of miRNAs in the region can distinguish high-aggressiveness versus low-aggressiveness osteosarcoma cell lines, and the levels of miR-495, miR329, miR-487b, miR-410, and miR-656 can predict the outcome of patients with osteosarcoma [107]. In addition, the expression pattern of miRNAs in the MEG3 region can also identify previously unrecognized distinct molecular subtypes of osteosarcoma. These findings suggest the possible therapeutic implications of miRNAs in the region.

LncRNAs play crucial roles in epigenetic regulation of gene expression through interactions with miRNAs, mRNAs and proteins [108]. MiRNAs can directly or indirectly affect the lncRNA expression level. 
Table 2: Changes of MEG3 expression level in different mouse models

\begin{tabular}{|c|c|c|c|c|c|c|c|}
\hline Reference & Cancer Type & Country & Samples & $\begin{array}{c}\text { Number of samples } \\
\text { case/control }\end{array}$ & $\begin{array}{c}\text { MEG3 } \\
\text { Level }\end{array}$ & Methods & Potential function and mechanism \\
\hline $\begin{array}{l}\text { Chunharojrith et al., } \\
2015 \text { [80] }\end{array}$ & NFAs & USA & Nude mice & $5 / 5$ & Down & RT-PCR & $\begin{array}{l}\text { MEG3 causes cell cycle arrest at the } \\
\text { G1 phase }\end{array}$ \\
\hline Luo et al., 2015 [60] & $\mathrm{PC}$ & China & Nude mice & $\begin{array}{l}\text { 5/5(pCDNA / } \\
\text { pCDNA-MEG3) }\end{array}$ & Down & qRT-PCR & $\begin{array}{l}\text { MEG3 inhibits the expression of cell } \\
\text { cycle regulatory protein Cyclin D1 and } \\
\text { induced cell cycle arrest in G0/G1 phase }\end{array}$ \\
\hline Yin et al., 2015 [54] & $\mathrm{CRC}$ & China & Nude mice & $3 / 3$ & Down & qRT-PCR & $\begin{array}{l}\text { The proliferation index ki- } 67 \text { is } \\
\text { significantly decreased in the MEG3- } \\
\text { transfected tumor cells. In addition, the } \\
\text { cleaved caspase- } 3 \text { level is increased. }\end{array}$ \\
\hline Zhuo et al., 2015 [34] & $\mathrm{HCC}$ & China & Nude mice & $5 / 5$ & Down & qRT-PCR & $\begin{array}{l}\text { MEG3 inhibits proliferation and induces } \\
\text { apoptosis through the accumulation of } \\
\text { TP53. }\end{array}$ \\
\hline Liu et al., 2015 [38] & LAD & China & $\begin{array}{l}\text { Nude mouse xenograft } \\
\text { model }\end{array}$ & $\begin{array}{l}6 / 6(\mathrm{pCDNA}-\mathrm{MEG} 3 / \\
\text { empty vector }+ \\
\text { cisplatin) }\end{array}$ & Down & qRT-PCR & $\begin{array}{l}\text { MEG3 overexpression increases the in } \\
\text { vivo chemosensitivity of LAD cells to } \\
\text { cisplatin. }\end{array}$ \\
\hline Modali et al., 2015 [62] & Insulinomas & USA & Mice & $7 / 6$ & Down & qRT-PCR & $\begin{array}{l}\text { DNA demethylating drugs reduce mouse } \\
\text { insulinoma cell proliferation and restore } \\
\text { MEG3 expression. }\end{array}$ \\
\hline Lu et al., 2013 [44] & NSCLC & China & Nude mice & $5 / 5$ & Down & qRT-PCR & $\begin{array}{l}\text { Overexpression of MEG } 3 \text { could inhibit } \\
\text { tumor growth in vivo. }\end{array}$ \\
\hline Lempiäinen et al., 2013 [82] & LT & UK & PB treatment Mice & 5 Pairs & Down & qRT-PCR & $\begin{array}{l}\text { PB induces MEG3 expression } \\
\text { in glutamine synthetase positive } \\
\text { hypertrophic hepatocytes. }\end{array}$ \\
\hline Gordon et al., 2010 [81] & PA & USA & Nude mice & 5 Pairs & Lost & qRT-PCR & $\begin{array}{l}\text { Increased expression of angiogenic } \\
\text { genes in the brains of MEG3-null mice. }\end{array}$ \\
\hline Kawakami et al., 2006 [46] & $\mathrm{RCC}$ & Japan & Nude mice & 5 Pairs & Lost & qRT-PCR & $\begin{array}{l}\text { Reintroduction of DLK1 into DLK1-null } \\
\text { RCC cell suppresses tumor growth in } \\
\text { nude mice. }\end{array}$ \\
\hline
\end{tabular}

Abbreviations: CRC; Colorectal cancer; HCC, Hepatocellular Carcinoma; LAD; lung adenocarcinoma, PA, pituitary adenomas; RCC, Renal Cell Carcinoma; LT, Liver Tumor; NSCLC, Non-small cell lung cancer.; NFAs, non-functioning pituitary adenomas.

Therefore, besides the changes of protein coding genes, it is necessary to investigate the epigenetic regulation of noncoding RNAs and the inter-relationship between miRNAs and lncRNAs to understand the underlying molecular processes involved in cancer development and progression. In a recent study, the down-regulated MEG3 in cervical cancer has been shown to affect cell proliferation and apoptosis through modulating the level of miR-21-5p [63]. In another study, the levels of miR-141 and MEG3 have been found to be significantly reduced in GC patients. Furthermore, E2F3 was identified as a target of miR-141, and its expression level was also found to be negatively associated with both MEG3 and miR-141 [57]. These findings may indicate the interaction between miR-141 and MEG3 to inhibit GC cell proliferation. Studies also showed that miR29 may involve in the regulation of MEG3 level which correlates with a poor prognosis of HCC $[41,109]$. These data suggest the involvement of miRNAs on tumor progression may be in part mediated through MEG3 activity.

Loss of imprinting/methylation changes in the 14q32 non-coding region defines reproducible previously unrecognized osteosarcoma subtypes with distinct transcriptional programs and biologic and clinical behavior. Future studies will define the precise relationship between 14q32 imprinting, non-coding RNA expression, genomic enhancer binding, and tumor aggressiveness, with possible therapeutic implications for both early- and advanced-stage patients.

\section{MEG3 involved in key cancer associated signaling pathways}

\section{p53 pathway}

The p53 (TP53) gene encodes a transcription factor, TP53, which has been associated with tumor development and growth [110]. The activation of TP53 leads to cell cycle arrest, replicative senescence, and/or apoptosis [111]. TP53 interacts with and affects other tumor suppressor activities including CDKN2A (cyclindependent kinase inhibitor 2A) [112], BRCA1 [113], and PTEN (phosphatase and tensin homolog [114] (Figure 1). Over-expressing MEG3 induces a significant increase of TP53 protein levels in HCT116 (colorectal cancer) and U2OS (osteosarcoma) cancer cell lines [115]. Further investigation demonstrated that over-expression of MEG3 promotes apoptotic cell death and induces $\mathrm{G} 2 / \mathrm{M}$ cell cycle arrest in cervical cancer (HeLa) and retinoblastoma (C33A) derived cell lines [49] through the decrease of CDK1 (cyclin-dependent Kinase 1) and CCNB1 (cyclin B1) levels [49, 63]. Abnormal expression of MEG3 induces apoptosis in $\mathrm{HCC}$ derived cell line - PRC/PRF/5 
and glioma derived cell lines - U251 and U87 through interaction with TP53 directly by MEG3. MEG3 also affects caspase 3 (CASP3) and p21 (CDKN1A) levels through the activation of TP53 [44, 49]. These findings suggested that the inhibition of tumor cell proliferation by MEG3 is partially due to the induction of G2/M cell cycle arrest and apoptosis by interacting with genes including CCNB1, CDK1 CDKN1A, CASP3 and TP53.

\section{MDM2 pathway}

MEG3 mitigates TP53 activation and can also be mediated through changing the activity of mouse double minute 2, human homolog (MDM2) (Figure 1). MDM2 encodes a nuclear E3 ubiquitin ligase that mediates ubiquitination of proteins including tumor suppressor proteins, such as TP53 for degradation [116, 117]. Recently, it has been reported that MDM2 expression is suppressed by MEG3. Inhibition of MDM2 through phosphorylation, acetylation, and sumoylation has an impact on TP53 activity [118-120]. The decreased MEG3 level down-regulates MDM2 expression which leads to an increase of TP53 protein level and enhances TP53 binding to its targeted promoters to stimulate p53dependent transcriptions [44, 115, 121]. In addition, it has been shown in a mouse model, the increase of MEG3 level up-regulates Tp53 by suppressing Mdm2 [81, 115].

MDM2 itself is also regulated by TP53 at transcription level; therefore, MDM2 and TP53 form an auto-regulatory feedback loop that may be needed to maintain a critical MDM2/TP53 ratio within a cell (Figure 1). Factors that differentially regulate the activities of MDM2 and TP53 may affect cell fate profoundly as they can change the ratio between MDM2 and TP53 [117]. These findings indicated the down-regulation of MDM2 is one of the mechanisms for MEG3 to affect TP53 dependent transcription. Therefore, MEG3 induced apoptosis and antiproliferative activities in cells may be mediated through the suppression of MDM2 and subsequent activation of TP53 signaling pathway $[115,122]$.

\section{MEG3 and GDF15}

MEG3 also enhances a TP53 dependent expression of growth differentiation factor 15 (GDF15), an inhibitor of cell proliferation, which is a member of the transforming growth factor- $\beta$ (TGFB) superfamily (Figure 1) [123]. Studies reported that GDF15 inhibits proliferation of several cancer cell lines in vitro as well as suppresses tumor formation in vivo [124, 125]. Zhou et al. demonstrated that GDF15 can be directly affected by MEG3 since re-expression of MEG3 in HCT116 cells induces GDF15 expression level and suppresses cell proliferation [115]. In addition, stimulation of GDF15 expression by MEG3 is through interaction with the GDF15 promoter region [115]. These findings showed that MEG3 not only regulates TP53 but also some TP53 targeted genes such as GDF15.

\section{pRb pathway}

Retinoblastoma $1(\mathrm{RB} 1)$ protein is an important tumor suppressor which is involved in cancer cell related processes including cell cycle, cell differentiation and apoptosis $[126,127]$. RB1 often inhibits tumor cell proliferation by regulating genes required for $\mathrm{G}$ to $\mathrm{S}$ phase transition and causes G1 cell cycle arrest [128, 129]. Phosphorylation of RB1 by cyclin D (CCND1)/cyclin dependent kinases (CDK4, CDK6) and cyclin E (CCNE1)/CDK2 complexes is necessary to restore the progression of cell cycle [130]. This process is balanced by negative cell cycle regulators, cyclin-dependent kinase inhibitors (CDKNs) which inhibit the G1 phase cyclin-CDK complexes [131]. RB1 can also regulate the stability and the apoptotic function of TP53 via MDM2 [132]. Since MEG3 affects the activities of MDM2 and TP53, it may indirectly affect RB1 mediated tumor suppressing function. In addition, MEG3 may activate RB1 directly by RNA-protein interactions or indirectly by activating CDKN4A, which in turn activates the RB1 to suppress cell proliferation and tumor formation [133].

\section{Other MEG3 associated pathways}

MEG3 has also been found to suppress cell proliferation and promote apoptosis through the VEGF pathway, Wnt/ $\beta$-catenin pathway and TGF- $\beta$ pathway in some cancers. For example, Gordon et al. observed a significantly increased microvessel formation in the brain together with the elevated expression of genes involved in VEGF angiogenic pathway in a MEG3 KO mice brain compared with normal wild type [81]. The increase of VEGF pathway activity in MEG3 KO mice brain suggests that MEG3 may play an important role in the progression for tumors like meningioma. In addition, one recent study showed that overexpression of MEG3 suppresses cell proliferation and promotes apoptosis by reducing the Wnt/ $\beta$-catenin pathway activity in retinoblastoma cell lines. Treating the cells with a Wnt/ $\beta$-catenin pathway activator reverses MEG3 over-expression induced anti-proliferation activity in retinoblastoma cell lines [77]. Using a modified chromatin oligo affinity precipitation method, Mondal et al. found some of the genes involved in TGF- $\beta$ pathway interact directly with MEG3 [134]. It has been suggested that MEG3 regulates the expression of its target genes through the formation of RNA-DNA triplex structures [134], which may be a general mechanism for gene regulation mediated by $\operatorname{lncRNAs}$.

\section{MEG3 and drug resistance in cancers}

Many studies have shown that processes related to drug resistance are modulated by lncRNAs [17]. For example, Yang et al. showed a significant decrease of 
MEG3 level in cisplatin-resistant A549/DDP lung cancer cells [18]. Furthermore, inducing the expression of MEG3 was able to re-sensitize the A549/DDP cells to cisplatin in vitro. The same study also demonstrated MEG3mediated chemosensitivity was associated with the induction of cell cycle arrest and increased apoptosis through genes in the WNT/ $\beta$ catenin signaling pathway such as TP53, $\beta$-catenin, and survival $[18,77]$. Similar to what has been observed in vitro, a decrease of MEG3 level has been found in cisplatin-resistant human lung adenocarcinoma (LAD) tissues accompanied with decreased TP53 and increased Bcl-xl protein levels [38]. Therefore, the level of MEG3 could be used as a potential biomarker to gauge the response to cisplatin based chemotherapy in lung cancer.

\section{Future prospect of MEG3 in human cancer}

Based on findings described in literatures, MEG3 is an RNA-based tumor suppressor and is involved in the etiology, progression, and chemosensitivity of cancers $[2,19,20,28,106,135-137]$. Its activity is mediated through both TP53-dependent and TP53-independent processes (Figure 1). MEG3 interacts with a number of well characterized tumor-related genes including TP53, MDM2, GDF15, RB1 and TGFB. Differential expression of MEG3 between normal and different grades of cancers offers the possibility of using MEG3 to assess the stage and prognosis of cancer $[2,138,139]$. The spectrum of lncRNAs including MEG3 in tissue samples can be measured by various profiling methods including microarray, next generation sequencing, and qPCR [140-142]. This may lead to a noninvasive, inexpensive and reliable method to monitor cancer progression and assess the prognosis of disease [138, 139, 143].

Modulating the levels of lncRNAs such as MEG3 through methods including over-expression, RNAi mediated gene silencing, or by small molecule inhibitors for cancer therapy looks promising in in vitro. Even though attempts have been made to improve the delivery system; to use lncRNA as a therapeutic target in vivo is still challenging, especially in reducing the off-targets effect and delivering the expressing vector or RNAi into specific cells [136, 138, 139, 144].

In summary, some lncRNAs like MEG3 are strongly associated with the clinicopathological outcome of various cancers. Lost or decreased expression of MEG3 is common in human cancers. The effects of MEG3 expression on cancer development are well-documented and MEG3 has been attributed as a tumor suppressor based on its involvement in tumor development. MEG3 can be used as a promising target for cancer diagnosis, prognosis and treatment; however, more fundamental work such as efforts to reduce immune response, minimize off-targets effects, and develop more effective targeted deliver system is needed in order to further develop possible clinical applications.

\section{Abbreviations}

AML-Acute myeloid leukemia; CASP3-Caspase 3; CCND1-Cyclin D; CCNB1-Cyclin B1; CDK1-Cyclindependent Kinase 1; CRC-Colorectal cancer; DFSDisease free survival; DMR-Differentially methylated region; ESCC-Esophageal squamous cell carcinoma; GC-Gastric cancer; GDF15-Growth differentiation factor 15; HCC-Hepatocellular carcinoma; IG-DMR-Intergenic differentially methylated region; KO-Knockout; LADLung adenocarcinoma; LncRNA-Long noncoding RNA; MDM2-Mouse double minute 2, human homolog; MEG3-Maternally expressed gene 3; miRNA-microRNA; NFPA-Nonfunctioning pituitary adenoma; NSCLCNon-small cell lung cancer; OS-Overall survival; RB1Retinoblastoma 1; snoRNA-Small nucleolar RNA; TNMTumor node metastasis.

\section{Author contributions}

All authors reviewed and approved the final version of the manuscript. Yuqing He conducted the initial literature review and drafted the article. Yanhong Luo, Guangxing Lu, Biyu Liang, Lei Ye and Weiming He, reviewed and summarized the literature.

\section{ACKNOWLEDGMENTS}

The authors wish to thanks critical reading from David Baxter, Kelsey Scherler and Kai Wang. The authors also want to acknowledge funding agencies including Talents Introduction Program of Guangdong Province "Yangfan Plan" 201433005 (Y.H.), Science and Technology Program of Guangdong 2013B051000080 (Y.H.), International Science \& Technology Cooperation Program of Dongguan 2013508152005 (Y.H.), Science \& Technology Program of Dongguan 2014108101055 (Y.H.), Industry-university-research Cooperation Project of Guangdong Medical University CXY201304 (Y.H.), and Natural Science Foundation of Guangdong Province 2015A030313517 (Y.H.).

\section{CONFLICTS OF INTEREST}

The authors declare no conflict of interest.

\section{REFERENCES}

1. He Y, Lin J, Kong D, Huang M, Xu C, Kim TK, Etheridge A, Luo Y, Ding Y, Wang K. Current State of Circulating MicroRNAs as Cancer Biomarkers. Clin Chem. 2015; 61:1138-1155.

2. Malek E, Jagannathan S, Driscoll JJ. Correlation of long non-coding RNA expression with metastasis, drug resistance and clinical outcome in cancer. Oncotarget. 2014; 5:8027-38. http://doi.org/10.18632/oncotarget.2469. 
3. Stepanov GA, Filippova JA, Komissarov AB, Kuligina EV, Richter VA, Semenov DV. Regulatory Role of Small Nucleolar RNAs in Human Diseases. Biomed Res Int. 2015; 2015:206849.

4. Louro R, Smirnova AS, Verjovski-Almeida S. Long intronic noncoding RNA transcription: expression noise or expression choice? Genomics. 2009; 93:291-298.

5. Ponting CP, Oliver PL, Reik W. Evolution and functions of long noncoding RNAs. Cell. 2009; 136:629-641.

6. Hung T, Chang HY. Long noncoding RNA in genome regulation: prospects and mechanisms. RNA Biol. 2010; 7:582-585.

7. Gibb EA, Brown CJ, Lam WL. The functional role of long non-coding RNA in human carcinomas. Mol Cancer. 2011; 10:38-55.

8. Mercer TR, Dinger ME, Mattick JS. Long non-coding RNAs: insights into functions. Nat Rev Genet. 2009; 10:155-159.

9. Qu J, Li M, Zhong W, Hu C. Competing endogenous RNA in cancer: a new pattern of gene expression regulation. Int $\mathrm{J}$ Clin Exp Med. 2015; 8:17110.

10. Sun R, Qin C, Jiang B, Fang S, Pan X, Peng L, Liu Z, Li W, Li Y, Li G. Down-regulation of MALAT1 inhibits cervical cancer cell invasion and metastasis by inhibition of epithelial-mesenchymal transition. Mol Biosyst. 2016; 12:952-62.

11. Chen CL, Tseng YW, Wu JC, Chen GY, Lin KC, Hwang $\mathrm{SM}, \mathrm{Hu}$ YC. Suppression of hepatocellular carcinoma by baculovirus-mediated expression of long non-coding RNA PTENP1 and MicroRNA regulation. Biomaterials. 2015; 44:71-81.

12. Liu Y, Zhao J, Zhang W, Gan J, Hu C, Huang G, Zhang Y. lncRNA GAS5 enhances G1 cell cycle arrest via binding to $\mathrm{YBX} 1$ to regulate $\mathrm{p} 21$ expression in stomach cancer. Sci Rep. 2015; 5:10159.

13. Ning Y, Yong F, Haibin Z, Hui S, Nan Z, Guangshun Y. LincRNA-p21 activates endoplasmic reticulum stress and inhibits hepatocellular carcinoma. Oncotarget. 2015; 6:28151-63. http://doi.org/10.18632/oncotarget.4661.

14. Raveh E, Matouk IJ, Gilon M, Hochberg A. The H19 Long noncoding RNA in cancer initiation, progression and metastasis-a proposed unifying theory. Mol Cancer. 2015; 14:1.

15. Roberts TC, Morris KV, Weinberg MS. Perspectives on the mechanism of transcriptional regulation by long non-coding RNAs. Epigenetics. 2014; 9:13-20.

16. Wang C, Yan G, Zhang Y, Jia X, Bo P. Long non-coding RNA MEG3 suppresses migration and invasion of thyroid carcinoma by targeting of Rac1. Neoplasma. 2015; 62:541-9.

17. Pan J, Xie X, Li X, Chen W. Long Non-coding RNAs and Drug Resistance. Asian Pac J Cancer P. 2014; 16:8067-8073.

18. Xia Y, He Z, Liu B, Wang P, Chen Y. Downregulation of Meg3 enhances cisplatin resistance of lung cancer cells through activation of the $\mathrm{WNT} / \beta$-catenin signaling pathway. Mol Med Rep. 2015; 12:4530-4537.
19. Fatima R, Akhade VS, Pal D, Rao SM. Long noncoding RNAs in development and cancer: potential biomarkers and therapeutic targets. Mol Cell Therapies. 2015; 3:1.

20. Meseure D, Alsibai KD, Nicolas A, Bieche I, Morillon A. Long non coding RNAs as new architects in cancer epigenetics, prognostic biomarkers and potential therapeutic. Bio Med Res Int. 2015; 2015.

21. Ricciuti B, Mencaroni C, Paglialunga L, Paciullo F, Crinò L, Chiari R, Metro G. Long noncoding RNAs: new insights into non-small cell lung cancer biology, diagnosis and therapy. Med Oncol. 2016; 33:1-12.

22. Cui X, Jing $X$, Long $C$, Tian J, Zhu J. Long noncoding RNA MEG3, a potential novel biomarker to predict the clinical outcome of cancer patients: a meta-analysis. Oncotarget. 2017; 8:19049-19056. http://doi.org/10.18632/ oncotarget. 14987.

23. Zhang J, Lin Z, Gao Y, Yao T. Downregulation of long noncoding RNA MEG3 is associated with poor prognosis and promoter hypermethylation in cervical cancer. J Exp Clin Cancer Res. 2017; 36:5.

24. Greife A, Knievel J, Ribarska T, Niegisch G, Schulz WA. Concomitant downregulation of the imprinted genes DLK1 and MEG3 at 14q32. 2 by epigenetic mechanisms in urothelial carcinoma. Clin Epigenetics. 2014; 6:29.

25. Zhang X, Rice K, Wang Y, Chen W, Zhong Y, Nakayama Y, Zhou Y, Klibanski A. Maternally expressed gene 3 (MEG3) noncoding ribonucleic acid: isoform structure, expression, and functions. Endocrinology. 2010; 151:939-947.

26. Xiu YL, Sun KX, Chen X, Chen S, Zhao Y, Guo QG, Zong $\mathrm{ZH}$. Upregulation of the lncRNA Meg3 induces autophagy to inhibit tumorigenesis and progression of epithelial ovarian carcinoma by regulating activity of ATG3. Oncotarget. 2017; 8:31714-31725. http://doi.org/10.18632/ oncotarget.15955.

27. Zhang CY, Yu MS, Li X, Zhang Z, Han CR, Yan B. Overexpression of long non-coding RNA MEG3 suppresses breast cancer cell proliferation, invasion, and angiogenesis through AKT pathway. Tumour Biol. 2017; 39:1010428317701311.

28. Zhou Y, Zhang X, Klibanski A. MEG3 noncoding RNA: a tumor suppressor. J Mol Endocrinol. 2012; 48:.45-R53.

29. Miyoshi N, Wagatsuma H, Wakana S, Shiroishi T, Nomura M, Aisaka K, Kohda T, Surani MA, Kaneko-Ishino T, Ishino F. Identification of an imprinted gene, Meg3/Gt12 and its human homologue MEG3, first mapped on mouse distal chromosome 12 and human chromosome 14q. Genes Cells. 2000; 5:211-220.

30. da Rocha ST, Edwards CA, Ito M, Ogata T, Ferguson-Smith AC. Genomic imprinting at the mammalian Dlk1-Dio3 domain. Trends Genet. 2008; 24:306-316.

31. Astuti D, Latif F, Wagner K, Gentle D, Cooper W, Catchpoole D, Grundy R, Ferguson-Smith A, Maher E. Epigenetic alteration at the DLK1-GTL2 imprinted domain in human neoplasia: analysis of neuroblastoma, 
phaeochromocytoma and Wilms' tumour. Br J Cancer. 2005; 92:1574-1580.

32. Zhao J, Dahle D, Zhou Y, Zhang X, Klibanski A. Hypermethylation of the promoter region is associated with the loss of MEG3 gene expression in human pituitary tumors. J Clin Endocrinol Metab. 2005; 90:2179-2186.

33. Benetatos L, Dasoula A, Hatzimichael E, Georgiou I, Syrrou M, Bourantas KL. Promoter hypermethylation of the MEG3 (DLK1/MEG3) imprinted gene in multiple myeloma. Clin Lymphoma Myeloma. 2008; 8:171-175.

34. Zhuo H, Tang J, Lin Z, Jiang R, Zhang X, Ji J, Wang P, Sun B. The aberrant expression of MEG3 regulated by UHRF1 predicts the prognosis of hepatocellular carcinoma. Mol Carcinog. 2016; 55:209-19.

35. Yan J, Guo X, Xia J, Shan T, Gu C, Liang Z, Zhao W, Jin S. MiR-148a regulates MEG3 in gastric cancer by targeting DNA methyltransferase 1. Med Oncol. 2014; 31:1-7.

36. Wang $\mathrm{P}$, Ren Z, Sun P. Overexpression of the long non-coding RNA MEG3 impairs in vitro glioma cell proliferation. J Cell Biochem. 2012; 113:1868-1874.

37. Ribarska T, Goering W, Droop J, Bastian KM, Ingenwerth M, Schulz WA. Deregulation of an imprinted gene network in prostate cancer. Epigenetics. 2014; 9:704-717.

38. Liu J, Wan L, Lu K, Sun M, Pan X, Zhang P, Lu B, Liu G, Wang Z. The Long Noncoding RNA MEG3 Contributes to Cisplatin Resistance of Human Lung Adenocarcinoma. PLoS One. 2015; 10:e0114586.

39. Hubertus J, Lacher M, Rottenkolber M, Müller-Höcker J, Berger M, Stehr M, Von Schweinitz D, Kappler R. Altered expression of imprinted genes in Wilms tumors. Oncol Rep. 2011; 25:817-823.

40. Gejman R, Batista DL, Zhong Y, Zhou Y, Zhang X, Swearingen B, Stratakis CA, Hedley-Whyte ET, Klibanski A. Selective loss of MEG3 expression and intergenic differentially methylated region hypermethylation in the MEG3/DLK1 locus in human clinically nonfunctioning pituitary adenomas. J Clin Endocrinol Metab. 2008; 93:4119-4125.

41. Braconi C, Kogure T, Valeri N, Huang N, Nuovo G, Costinean S, Negrini M, Miotto E, Croce C, Patel T. microRNA-29 can regulate expression of the long noncoding RNA gene MEG3 in hepatocellular cancer. Oncogene. 2011; 30:4750-4756.

42. Binse I, Ueberberg B, Sandalcioglu I, Flitsch J, Luedecke D, Mann K, Petersenn S. Expression Analysis of GADD45 $\gamma$, MEG3, and p8 in Pituitary Adenomas. Horm Metab Res. 2014; 46:644-650.

43. Mezzomo LC, Gonzales PH, Pesce FG, Kretzmann Filho N, Ferreira NP, Oliveira MC, Kohek MBF. Expression of cell growth negative regulators MEG3 and GADD45 $\gamma$ is lost in most sporadic human pituitary adenomas. Pituitary. 2012; 15:420-427.

44. Lu KH, Li W, Liu XH, Sun M, Zhang ML, Wu WQ, Xie WP, Hou YY. Long non-coding RNA MEG3 inhibits
NSCLC cells proliferation and induces apoptosis by affecting p53 expression. BMC Cancer. 2013; 13:461.

45. Li Z, Li C, Liu C, Yu S, Zhang Y. Expression of the long non-coding RNAs MEG3, HOTAIR, and MALAT-1 in non-functioning pituitary adenomas and their relationship to tumor behavior. Pituitary. 2014; 18:42-47.

46. Kawakami T, Chano T, Minami K, Okabe H, Okada Y, Okamoto K. Imprinted DLK1 is a putative tumor suppressor gene and inactivated by epimutation at the region upstream of GTL2 in human renal cell carcinoma. Hum Mol Genet. 2006; 15:821-830.

47. Jia LF, Wei SB, Gan YH, Guo Y, Gong K, Mitchelson K, Cheng J, Yu GY. Expression, regulation and roles of miR26a and MEG3 in tongue squamous cell carcinoma. Int $\mathrm{J}$ Cancer. 2014; 135:2282-2293.

48. Sheng X, Li J, Yang L, Chen Z, Zhao Q, Tan L, Zhou Y, Li J. Promoter hypermethylation influences the suppressive role of maternally expressed 3 , a long non-coding RNA, in the development of epithelial ovarian cancer. Oncol Rep. 2014; 32:277-285.

49. Qin R, Chen Z, Ding Y, Hao J, Hu J, Guo F. Long noncoding RNA MEG3 inhibits the proliferation of cervical carcinoma cells through the induction of cell cycle arrest and apoptosis. Neoplasma. 2012; 60:486-492.

50. Shiah SG, Hsiao JR, Chang WM, Chen YW, Jin YT, Wong TY, Huang JS, Tsai ST, Hsu YM, Chou ST. Downregulated miR329 and miR410 promote the proliferation and invasion of oral squamous cell carcinoma by targeting Wnt-7b. Cancer Res. 2014; 74:7560-7572.

51. Wang M, Huang T, Luo G, Huang C, Xiao XY, Wang L, Jiang GS, Zeng FQ. Long non-coding RNA MEG3 induces renal cell carcinoma cells apoptosis by activating the mitochondrial pathway. J Huazhong Univ Sci Technolog Med Sci. 2015; 35:541-545.

52. Zhuang W, Ge X, Yang S, Huang M, Zhuang W, Chen P, Zhang X, Fu J, Qu J, Li B. Upregulation of lncRNA MEG3 Promotes Osteogenic Differentiation of Mesenchymal Stem Cells From Multiple Myeloma Patients By Targeting BMP4 Transcription. Stem Cells. 2015; 33:1985-1997.

53. Ying L, Huang Y, Chen H, Wang Y, Xia L, Chen Y, Liu Y, Qiu F. Downregulated MEG3 activates autophagy and increases cell proliferation in bladder cancer. Mol Biosyst. 2013; 9:407-411.

54. Yin DD, Liu ZJ, Zhang E, Kong R, Zhang ZH, Guo RH. Decreased expression of long noncoding RNA MEG3 affects cell proliferation and predicts a poor prognosis in patients with colorectal cancer. Tumor Biol. 2015; 36:4851-9.

55. Li C, Liang G, Yao W, Sui J, Shen X, Zhang Y, Ma S, Ye Y, Zhang Z, Zhang W, Yin L, Pu Y. Differential expression profiles of long non-coding RNAs reveal potential biomarkers for identification of human gastric cancer. Oncol Rep. 2016; 35:1529-1540.

56. Li J, Bian EB, He XJ, Ma CC, Zong G, Wang HL, Zhao B. Epigenetic repression of long non-coding RNA MEG3 
mediated by DNMT1 represses the $\mathrm{p} 53$ pathway in gliomas. Int J Oncol. 2016; 48:723-733.

57. Zhou X, Ji G, Ke X, Gu H, Jin W, Zhang G. MiR-141 inhibits gastric cancer proliferation by interacting with long noncoding RNA MEG3 and down-regulating E2F3 expression. Dig Dis Sci. 2015; 60:3271-3282.

58. Tian ZZ, Guo XJ, Zhao YM, Fang Y. Decreased expression of long non-coding RNA MEG3 acts as a potential predictor biomarker in progression and poor prognosis of osteosarcoma. Int J Clin Exp Pathol. 2015; 8:15138-15142.

59. Peng W, Si S, Zhang Q, Li C, Zhao F, Wang F, Yu J, Ma R. Long non-coding RNA MEG3 functions as a competing endogenous RNA to regulate gastric cancer progression. J Exp Clin Cancer Res. 2015; 34:79.

60. Luo G, Wang M, Wu X, Tao D, Xiao X, Wang L, Min F, Zeng F, Jiang G. Long Non-Coding RNA MEG3 Inhibits Cell Proliferation and Induces Apoptosis in Prostate Cancer. Cell Physiol Biochem. 2015; 37:2209-2220.

61. Cheunsuchon P, Zhou Y, Zhang X, Lee H, Chen W, Nakayama Y, Rice KA, Hedley-Whyte ET, Swearingen B, Klibanski A. Silencing of the imprinted DLK1-MEG3 locus in human clinically nonfunctioning pituitary adenomas. Am J Pathol. 2011; 179:2120-2130.

62. Modali SD, Parekh VI, Kebebew E, Agarwal SK. Epigenetic regulation of the lncRNA MEG3 and its target c-MET in pancreatic neuroendocrine tumors. Mol Endocrinol. 2015; 29:224-237.

63. Zhang J, Yao T, Wang Y, Yu J, Liu Y, Lin Z. Long noncoding RNA MEG3 is downregulated in cervical cancer and affects cell proliferation and apoptosis by regulating miR-21. Cancer Biol Ther. 2016; 17:104-113.

64. Zhang X, Zhou Y, Mehta KR, Danila DC, Scolavino S, Johnson SR, Klibanski A. A pituitary-derived MEG3 isoform functions as a growth suppressor in tumor cells. J Clin Endocrinol Metab. 2003; 88:5119-5126.

65. Zhang X, Gejman R, Mahta A, Zhong Y, Rice KA, Zhou Y, Cheunsuchon P, Louis DN, Klibanski A. Maternally expressed gene 3, an imprinted noncoding RNA gene, is associated with meningioma pathogenesis and progression. Cancer Res. 2010; 70:2350-2358.

66. Zhu J, Liu S, Ye F, Shen Y, Tie Y, Wei L, Jin Y, Fu H, Wu Y, Zheng X. Long Noncoding RNA MEG3 Interacts with p53 Protein and Regulates Partial p53 Target Genes in Hepatoma Cells. PloS one. 2015; 10:0139790.

67. Tang W, Dong K, Li K, Dong R, Zheng S. MEG3, HCN3 and linc01105 influence the proliferation and apoptosis of neuroblastoma cells via the HIF-1alpha and p53 pathways. Sci Rep. 2016; 6:36268.

68. Li J, Zi Y, Wang W, Li Y. LncRNA MEG3 Inhibits Cell Proliferation and Metastasis in Chronic Myeloid Leukemia via Targeting MiR-184. Oncol Res. 2017. http://doi.org/ 10 .3727/096504017X14980882803151. [Epub ahead of print].

69. Lyu Y, Lou J, Yang Y, Feng J, Hao Y, Huang S, Yin L, $\mathrm{Xu}$ J, Huang D, Ma B, Zou D, Wang Y, Zhang Y, et al.
Dysfunction of the WT1-MEG3 signaling promotes AML leukemogenesis via p53-dependent and -independent pathways. Leukemia. 2017. http://doi.org/10.1038/ leu.2017.116. [Epub ahead of print].

70. Yao H, Sun P, Duan M, Lin L, Pan Y, Wu C, Fu X, Wang H, Guo L, Jin T, Ding Y. microRNA-22 can regulate expression of the long non-coding RNA MEG3 in acute myeloid leukemia. Oncotarget. 2017. http://doi.org/10.18632/ oncotarget.18059. [Epub ahead of print].

71. Zhang W, Shi S, Jiang J, Li X, Lu H, Ren F. LncRNA MEG3 inhibits cell epithelial-mesenchymal transition by sponging miR-421 targeting E-cadherin in breast cancer. Biomed Pharmacother. 2017; 91:312-319.

72. Gu L, Zhang J, Shi M, Zhan Q, Shen B, Peng C. IncRNA MEG3 had anti-cancer effects to suppress pancreatic cancer activity. Biomed Pharmacother. 2017; 89:1269-1276.

73. Yao H, Duan M, Lin L, Wu C, Fu X, Wang H, Guo L, Chen W, Huang L, Liu D, Rao R, Wang S, Ding Y. TET2 and MEG3 promoter methylation is associated with acute myeloid leukemia in a Hainan population. Oncotarget. 2017; 8:18337-18347. http://doi.org/10.18632/oncotarget.15440.

74. Hu D, Su C, Jiang M, Shen Y, Shi A, Zhao F, Chen R, Shen Z, Bao J, Tang W. Fenofibrate inhibited pancreatic cancer cells proliferation via activation of p53 mediated by upregulation of LncRNA MEG3. Biochem Biophys Res Commun. 2016; 471:290-295.

75. Parekh VI, Modali SD, Desai SS, Agarwal SK. Consequence of Menin Deficiency in Mouse Adipocytes Derived by In Vitro Differentiation. Int J Endocrinol. 2015; 2015:149826.

76. Qi P, Xu MD, Ni SJ, Shen XH, Wei P, Huang D, Tan C, Sheng WQ, Zhou XY, Du X. Down-regulation of ncRAN, a long non-coding RNA, contributes to colorectal cancer cell migration and invasion and predicts poor overall survival for colorectal cancer patients. Mol Carcinog. 2015; 54:742750.

77. Gao Y, Lu X. Decreased expression of MEG3 contributes to retinoblastoma progression and affects retinoblastoma cell growth by regulating the activity of $\mathrm{Wnt} / \beta$-catenin pathway. Tumor Biol. 2016; 37:1461-9.

78. Wang Y, Li RW, Li XT, Xin Y. Decreased long non-coding RNA MEG3 expression is associated with survival outcome and lymph node metastasis: a meta-analysis. Int J Clin Exp Med. 2017; 10.

79. Wang Y, Kong D. Knockdown of lncRNA MEG3 inhibits viability, migration and invasion and promotes apoptosis by sponging miR-127 in osteosarcoma cell. J Cell Biochem. 201. http://doi.org/10.1002/jcb.26230. [Epub ahead of print].

80. Chunharojrith P, Nakayama Y, Jiang X, Kery RE, Ma J, De La Hoz Ulloa CS, Zhang X, Zhou Y, Klibanski A. Tumor suppression by MEG3 lncRNA in a human pituitary tumor derived cell line. Mol Cell Endocrinol. 2015; 416:27-35.

81. Gordon FE, Nutt CL, Cheunsuchon P, Nakayama Y, Provencher KA, Rice KA, Zhou Y, Zhang X, Klibanski 
A. Increased expression of angiogenic genes in the brains of mouse meg3-null embryos. Endocrinology. 2010; 151:2443-2452.

82. Lempiäinen H, Couttet P, Bolognani F, Müller A, Dubost V, Luisier R, Espinola ADR, Vitry V, Unterberger E, Thomson JP. Identification of Dlk1-Dio3 imprinted gene cluster noncoding RNAs as novel candidate biomarkers for liver tumor promotion. Toxicol Sci. 2013; 131:375-386.

83. Takahashi N, Okamoto A, Kobayashi R, Shirai M, Obata Y, Ogawa H, Sotomaru Y, Kono T. Deletion of Gt12, imprinted non-coding RNA, with its differentially methylated region induces lethal parent-origin-dependent defects in mice. Hum Mol Genet. 2009; 18:1879-1888.

84. Sauvageau M, Goff LA, Lodato S, Bonev B, Groff AF, Gerhardinger C, Sanchez-Gomez DB, Hacisuleyman E, Li E, Spence M. Multiple knockout mouse models reveal lincRNAs are required for life and brain development. Elife. 2013; 2:e01749.

85. Benetatos L, Hatzimichael E, Dasoula A, Dranitsaris G, Tsiara S, Syrrou M, Georgiou I, Bourantas KL. CpG methylation analysis of the MEG3 and SNRPN imprinted genes in acute myeloid leukemia and myelodysplastic syndromes. Leuk Res. 2010; 34:148-153.

86. Kagami M, O’Sullivan MJ, Green AJ, Watabe Y, Arisaka O, Masawa N, Matsuoka K, Fukami M, Matsubara K, Kato F. The IG-DMR and the MEG3-DMR at human chromosome 14q32. 2: hierarchical interaction and distinct functional properties as imprinting control centers. PLoS Genet. 2010; 6:1000992.

87. Ganot P, Bortolin ML, Kiss T. Site-specific pseudouridine formation in preribosomal RNA is guided by small nucleolar RNAs. Cell. 1997; 89:799-809.

88. Sahoo T, del Gaudio D, German JR, Shinawi M, Peters SU, Person RE, Garnica A, Cheung SW, Beaudet AL. PraderWilli phenotype caused by paternal deficiency for the HBII85 C/D box small nucleolar RNA cluster. Nat Genet. 2008; 40:719-721.

89. Bortolin-Cavaillé ML, Cavaillé J. The SNORD115 (H/ MBII-52) and SNORD116 (H/MBII-85) gene clusters at the imprinted Prader-Willi locus generate canonical box C/D snoRNAs. Nucleic Acids Res. 2012; 40:6800-6807.

90. Cavaillé J, Nicoloso M, Bachellerie JP. Targeted ribose methylation of RNA in vivo directed by tailored antisense RNA guides. Nature. 1996; 383:732-735.

91. Valleron W, Laprevotte E, Gautier E, Quelen C, Demur C, Delabesse E, Agirre X, Prosper F, Kiss T, Brousset P. Specific small nucleolar RNA expression profiles in acute leukemia. Leukemia. 2012; 26:2052-2060.

92. Ferreira HJ, Heyn H, Moutinho C, Esteller M. CpG island hypermethylation-associated silencing of small nucleolar RNAs in human cancer. RNA Biol. 2012; 9:881-890.

93. Gattolliat C, Thomas L, Ciafre S, Meurice G, Le Teuff G, Job B, Richon C, Combaret V, Dessen P, Valteau-Couanet D. Expression of miR-487b and miR-410 encoded by 14q32. 31 locus is a prognostic marker in neuroblastoma. Br J Cancer. 2011; 105:1352-1361.

94. Liu L, Jiang Y, Zhang H, Greenlee AR, Han Z. Overexpressed miR-494 down-regulates PTEN gene expression in cells transformed by anti-benzo (a) pyrene-trans-7, 8-dihydrodiol-9, 10-epoxide. Life Sci. 2010; 86:192-198.

95. Swarbrick A, Woods SL, Shaw A, Balakrishnan A, Phua Y, Nguyen A, Chanthery Y, Lim L, Ashton LJ, Judson RL. miR-380-5p represses p53 to control cellular survival and is associated with poor outcome in MYCN-amplified neuroblastoma. Nat Med. 2010; 16:1134-1140.

96. Benetatos L, Hatzimichael E, Londin E, Vartholomatos G, Loher P, Rigoutsos I, Briasoulis E. The microRNAs within the DLK1-DIO3 genomic region: involvement in disease pathogenesis. Cell Mol Life Sci. 2013; 70:795-814.

97. Benetatos L, Voulgaris E, Vartholomatos G. DLK1-MEG3 imprinted domain microRNAs in cancer biology. Crit Rev Eukaryot Gene Expr. 2012; 22:1-15.

98. Dixon-McIver A, East P, Mein CA, Cazier JB, Molloy G, Chaplin T, Andrew Lister T, Young BD, Debernardi S. Distinctive patterns of microRNA expression associated with karyotype in acute myeloid leukaemia. PloS One. 2008; 3:2141.

99. Shih KK, Qin LX, Tanner EJ, Zhou Q, Bisogna M, Dao F, Olvera N, Viale A, Barakat RR, Levine DA. A microRNA survival signature (MiSS) for advanced ovarian cancer. Gynecol Oncol. 2011; 121:444-450.

100. Ye G, Fu G, Cui S, Zhao S, Bernaudo S, Bai Y, Ding Y, Zhang Y, Yang BB, Peng C. MicroRNA 376c enhances ovarian cancer cell survival by targeting activin receptorlike kinase 7: implications for chemoresistance. J Cell Sci. 2011; 124:359-368.

101. Chira P, Vareli K, Sainis I, Papandreou C, Briasoulis E. Alterations of microRNAs in solid cancers and their prognostic value. Cancers. 2010; 2:1328-1353.

102. Haller F, von Heydebreck A, Zhang JD, Gunawan B, Langer C, Ramadori G, Wiemann S, Sahin Ö. Localizationand mutation-dependent microRNA (miRNA) expression signatures in gastrointestinal stromal tumours (GISTs), with a cluster of co-expressed miRNAs located at 14q32. 31. J Pathol. 2010; 220:71-86.

103. Roccaro AM, Sacco A, Chen C, Runnels J, Leleu X, Azab F, Azab AK, Jia X, Ngo HT, Melhem MR. microRNA expression in the biology, prognosis, and therapy of Waldenström macroglobulinemia. Blood. 2009; 113:4391-4402.

104. Ueda T, Volinia S, Okumura H, Shimizu M, Taccioli C, Rossi S, Alder H, Liu CG, Oue N, Yasui W. Relation between microRNA expression and progression and prognosis of gastric cancer: a microRNA expression analysis. Lancet Oncol. 2010; 11:136-146.

105. Zamani M, Sadeghizadeh M, Behmanesh M, Najafi F. Dendrosomal curcumin increases expression of the long non-coding RNA gene MEG3 via up-regulation of epi-miRs in hepatocellular cancer. Phytomedicine. 2015; 22:961-967. 
106. Peng L, Yuan X, Jiang B, Tang Z, Li G-C. LncRNAs: key players and novel insights into cervical cancer. Tumor Biol. 2016; 37:2779-88.

107. Hill KE, Kelly AD, Kuijjer ML, Barry W, Rattani A, Garbutt CC, Kissick H, Janeway K, Perez-Atayde A, Goldsmith J, Gebhardt MC, Arredouani MS, Cote G, et al. An imprinted non-coding genomic cluster at $14 \mathrm{q} 32$ defines clinically relevant molecular subtypes in osteosarcoma across multiple independent datasets. J Hematol Oncol. 2017; 10:107.

108. Wan X, Ding X, Chen S, Song H, Jiang H, Fang Y, Li P, Guo J. The functional sites of miRNAs and lncRNAs in gastric carcinogenesis. Tumor Biol. 2015; 36:521-532.

109. Xiong Y, Fang JH, Yun JP, Yang J, Zhang Y, Jia WH, Zhuang SM. Effects of MicroRNA-29 on apoptosis, tumorigenicity, and prognosis of hepatocellular carcinoma. Hepatology. 2010; 51:836-845.

110. Vousden KH, Prives C. Blinded by the light: the growing complexity of p53. Cell. 2009; 137:413-431.

111. Vogelstein B, Lane D, Levine AJ. Surfing the p53 network. Nature. 2000; 408:307-310.

112. Sherr CJ, Weber JD. The ARF/p53 pathway. Curr Opin Genet Dev. 2000; 10:94-99.

113. Ouchi T, Monteiro AN, August A, Aaronson SA, Hanafusa H. BRCA1 regulates p53-dependent gene expression. Proc Natl Acad Sci U S A. 1998; 95:2302-2306.

114. Mayo LD, Donner DB. The PTEN, Mdm2, p53 tumor suppressor-oncoprotein network. Trends Biochem Sci. 2002; 27:462-467.

115. Zhou Y, Zhong Y, Wang Y, Zhang X, Batista DL, Gejman R, Ansell PJ, Zhao J, Weng C, Klibanski A. Activation of p53 by MEG3 non-coding RNA. J Biol Chem. 2007; 282:24731-24742.

116. Brooks CL, Gu W. p53 regulation by ubiquitin. FEBS Lett. 2011; 585:2803-2809.

117. Haupt Y, Maya R, Kazaz A, Oren M. Mdm2 promotes the rapid degradation of p53. Nature. 1997; 387:296-299.

118. Harris SL, Levine AJ. The p53 pathway: positive and negative feedback loops. Oncogene. 2005; 24:2899-2908.

119. Kubbutat MH, Jones SN, Vousden KH. Regulation of p53 stability by Mdm2. Nature. 1997; 387:299-303.

120. Wu X, Bayle JH, Olson D, Levine AJ. The p53-mdm-2 autoregulatory feedback loop. Genes Dev. 1993; 7:1126-1132.

121. Michael D, Oren M. The p53-Mdm2 module and the ubiquitin system. Semin Cancer Biol. 2003; 13:49-58.

122. Benetatos L, Vartholomatos G, Hatzimichael E. MEG3 imprinted gene contribution in tumorigenesis. Int J Cancer. 2011; 129:773-779.

123. Böttner M, Krieglstein K, Unsicker K. The transforming growth factor- $\beta$ s. J Neurochem. 2000; 75:2227-2240.

124. Albertoni M, Shaw PH, Nozaki M, Godard S, Tenan M, Hamou MF, Fairlie DW, Breit SN, Paralkar VM, de Tribolet N, Van Meir EG, Hegi ME. Anoxia induces macrophage inhibitory cytokine-1 (MIC-1) in glioblastoma cells independently of p53 and HIF-1. Oncogene. 2002; 21:4212-4219.

125. Li PX, Wong J, Ayed A, Ngo D, Brade AM, Arrowsmith C, Austin RC, Klamut HJ. Placental transforming growth factor- $\beta$ is a downstream mediator of the growth arrest and apoptotic response of tumor cells to DNA damage and p53 overexpression. J Biol Chem. 2000; 275:20127-20135.

126. Sherr CJ. Cancer cell cycles. Science. 1996; 274:1672-1677.

127. Mathivanan J, Rohini K, Gope ML, Anandh B, Gope R. Altered structure and deregulated expression of the tumor suppressor gene retinoblastoma (RB1) in human brain tumors. Mol Cell Biochem. 2007; 302:67-77.

128. Ma D, Zhou P, Harbour JW. Distinct mechanisms for regulating the tumor suppressor and antiapoptotic functions of Rb. J Biol Chem. 2003; 278:19358-19366.

129. Giacinti C, Giordano A. RB and cell cycle progression. Oncogene. 2006; 25:5220-5227.

130. Lundberg AS, Weinberg RA. Functional inactivation of the retinoblastoma protein requires sequential modification by at least two distinct cyclin-cdk complexes. Mol Cell Biol. 1998; 18:753-761.

131. Weinberg RA. The retinoblastoma protein and cell cycle control. Cell. 1995; 81:323-330.

132. Hsieh JK, Chan FS, O'Connor DJ, Mittnacht S, Zhong S, $\mathrm{Lu}$ X. RB regulates the stability and the apoptotic function of p53 via MDM2. Mol Cell. 1999; 3:181-193.

133. Al-Khalaf HH, Lach B, Allam A, Hassounah M, AlKhani A, Elkum N, Alrokayan SA, Aboussekhra A. Expression of survivin and $\mathrm{p} 16 \mathrm{INK} 4 \mathrm{a} / \mathrm{Cdk} 6 / \mathrm{pRB}$ proteins and induction of apoptosis in response to radiation and cisplatin in meningioma cells. Brain Res. 2008; 1188:25-34.

134. Mondal T, Subhash S, Vaid R, Enroth S, Uday S, Reinius B, Mitra S, Mohammed A, James AR, Hoberg E, Moustakas A, Gyllensten U, Jones SJ, et al. MEG3 long noncoding RNA regulates the TGF-beta pathway genes through formation of RNA-DNA triplex structures. Nat Commun. 2015; 6:7743.

135. Balik V, Srovnal J, Sulla I, Kalita O, Foltanova T, Vaverka M, Hrabalek L, Hajduch M. MEG3: a novel long noncoding potentially tumour-suppressing RNA in meningiomas. $\mathrm{J}$ Neurooncol. 2013; 112:1-8.

136. Kladi-Skandali A, Michaelidou K, Scorilas A, Mavridis K. Long Noncoding RNAs in Digestive System Malignancies: A Novel Class of Cancer Biomarkers and Therapeutic Targets? Gastroenterol Res Pract. 2015; 2015:319861.

137. Li T, Mo X, Fu L, Xiao B, Guo J. Molecular mechanisms of long noncoding RNAs on gastric cancer. Oncotarget. 2016; 7:8601-12. http://doi.org/10.18632/oncotarget.6926.

138. Qi P, Du X. The long non-coding RNAs, a new cancer diagnostic and therapeutic gold mine. Mod Pathol. 2013; 26:155-165.

139. Yarmishyn AA, Kurochkin IV. Long noncoding RNAs: a potential novel class of cancer biomarkers. Front Genet. 2015; 6:145. 
140. Feng Y, Hu X, Zhang Y, Zhang D, Li C, Zhang L. Methods for the Study of Long Noncoding RNA in Cancer Cell Signaling. Methods Mol Biol. 2014; 1165:115-143.

141. Hu X, Feng Y, Hu Z, Zhang Y, Yuan CX, Xu X, Zhang L. Detection of Long Noncoding RNA Expression by Nonradioactive Northern Blots. Methods Mol Biol. 2016; 1402:177-188.

142. Zhang Z, Weaver DL, Olsen D, Peng Z, Ashikaga T, Evans MF. Long non-coding RNA chromogenic in situ hybridisation signal pattern correlation with breast tumour pathology. J Clin Pathol. 2016; 69:76-81.
143. Gao J, Cao R, Mu H. Long non-coding RNA UCA1 may be a novel diagnostic and predictive biomarker in plasma for early gastric cancer. Int J Clin Exp Pathol. 2015; 8:12936.

144. Colombo S, Zeng X, Ragelle H, Foged C. Complexity in the therapeutic delivery of RNAi medicines: an analytical challenge. Expert Opin Drug Deliv. 2014; 11:1481-1495. 